Jurnal Professional FIS UNIVED Vol.7 No.1 Juni 2020

\title{
PENERAPAN RESPONSIBILITAS DAN TRANSPARANSI LAYANAN PUBLIK ( Sebuah Kajian Ilmu Administrasi)
}

Oleh:

\author{
ASTRI DWI S, SRI INDARTI, NOVLIZA EKA PATRISIA \\ Program Studi Administrasi Publik Fakultas Ilmu Sosial dan IImu Politik \\ Universitas Muhammadiyah Bengkulu
}

\begin{abstract}
The number of complaints and complaints from the public on government services, both directly and indirectly, or through the mass media, such as complaints about convoluted service procedures, lack of certainty in the period of settlement, the amount of costs to be incurred, the absence of requirements transparency, and the attitude of officers or employees who are less responsive is a program faced in public services. The formulation of the problem in this study is how the application of responsibility and transparency in the Bengkulu Province Regional Financial Management Agency To obtain answers to the research problems, researchers used qualitative research methods. From the results of the study it was found that Transparency in the Office of the Regional Financial Management Agency of Bengkulu Province has implemented the principle of transparency to assist in the provision of services to the public that is helping to facilitate payments. The application of the principle of responsibility in the Office of the Regional Financial Management Agency of Bengkulu Province can be seen from the extent of the implementation of the activities of the Office of the Regional Financial Management Agency of Bengkulu Province in carrying out its duties and responsibilities to the community, for example with the satisfaction of service to the community, the constraints obtained in this responsibility, namely the service given is not satisfactory for the community because it has not yet completed the office facilities of the Bengkulu Province Regional Financial Management Office in accordance with applicable principles.
\end{abstract}

Keywords: responsibilitas, transparansi, layanan publik

\section{PENDAHULUAN}

Dalam kehidupan berbangsa dan bernegara, maka pemerintah memiliki fungsi memberikan berbagai hal yang diperlukan oleh masyarakat, mulai dari bentuk pengaturan ataupun yang lain dalam rangka memenuhi kebutuhan masyarakat dalam bidang pendidikan, kesehatan, utilitas, dan lainnya. Peningkatan responsibilitas dan transparasi mutlak diperlukan mengingat kondisi sosial masyarakat yang semakin baik sehingga mampu merespon setiap penyimpangan dalam responsibilitas dan transparansi melalui gerakan maupun tuntutan dalam media cetak dan elektronik.

Dengan adanya persaingan terutama untuk responsibilitas dan transparasi yang disediakan swasta membuat sedikit saja pelanggan merasakan ketidakpuasan maka akan segera beralih pada penyedia pelayanan publik yang lain. Hal ini membuat 
penyedia pelayanan publik harus berlomba-lomba memberikan pelayanan publik yang terbaik. Ini yang seharusnya ditiru oleh penyedia pelayanan publik pemerintah sehingga masyarakat merasa puas menikmati pelayanan publik tersebut.

Responsibilitas dan transparansi dikembangkan berdasarkan client yaitu mendudukan diri bahwa warga negaralah yang membutuhkan responsibilitas dan transparasi, membutuhkan bantuan birokrasi. Sehingga responsibilitas dan transparasi yang dikembangkan adalah pelayanan yang independen dan menciptakan dependensi bagi warga negara dalam urusannya sebagai warga negara. Warga negara atau masyarakat dianggap sebagai follower dalam setiap kebijakan, ataupun program. Masyarakat dianggap sebagai makhluk yang "manut", selalu menerima setiap aktivitas birokrasi, padahal terkadang pemerintah melakukan aktivitas yang tidak selalu menguntungkan bagi masyarakat (Dwiyanto, 2006:59).

Masih banyaknya masalah yang menimpa masyarakat mengenai responsibilitas dan transparasi, seperti masalah perijinan, pembuatan, perpanjangan surat-surat yang dibutuhkan masyarakat, misalnya pembuatan KTP, Kartu Keluarga, Pajak kendaraan bermotor dan surat-surat pengantar untuk diajukan ke instansi yang lebih tinggi. Masalah timbul dari masyarakat sebagai konsumen yang tidak merasa puas dengan responsibilitas dan transparasi yang diberikan.

Badan Pengelola Keuangan Daerah (BPKD) mempunyai tugas melaksanakan fungsi penunjang urusan pemerintahan bidang keuangan. Adapun fungsi BPKD adalah sebagai penyusunan rencana strategis dan rencana kerja dan anggaran BPKD, pelaksanaan rencana strategis dan dokumen pelaksanaan anggaran BPKD, penyusunan dan penyelenggaraan kebijakan, pedoman dan standar teknis pengelolaan keuangan daerah, penyusunan KUA/KUPA berkoordinasi dengan Bappeda, penyusunan PPAS berkoordinasi dengan Bappeda, penyusunan rancangan
APBD, pergeseran belanja dan rancangan perubahan APBD berkoordinasi dengan Bappeda, pelaksanaan pemungutan pendapatan daerah, penyusunan laporan keuangan daerah dalam rangka pertanggungjawaban pelaksanaan APBD, penyusunan kebijakan dan pedoman pelaksanaan APBD, pengesahan DPA/DPPA-SKPD/UKPD, pengendalian pelaksanaan $\mathrm{APBD}$, pemberian petunjuk teknis pelaksanaan sistem penerimaan dan pengeluaran kas daerah, pemantauan pelaksanaan penerimaan dan pengeluaran APBD oleh bank dan/atau lembaga-lembaga keuangan lainnya yang telah ditunjuk, pengusahaan dan pengaturan dana yang diperlukan dalam pelaksanaan APBD, serta penyimpanan uang daerah.

Banyaknya keluhan dan pengaduan dari masyarakat terhadap pelayanan dari pemerintah baik yang secara langsung maupun melalui media massa, seperti keluhan terhadap prosedur yang berbelit-belit, tidak adanya kepastian jangka waktu penyelesaian, besaran biaya yang harus dikeluarkan, persyaratan yang tidak adanya transparansi, dan sikap petugas ataupun pegawai yang kurang responsif. Hal-hal inilah yang menimbulkan citra yang buruk kepada pemerintah. Padahal pegawai negeri sebagai aparat birokrasi selain sebagai aparatur negara dan abdi negara, memiliki peran sebagai abdi masyarakat. Sehingga kepada kepentingan masyarakatlah aparat birokrasi harusnya mengabdikan diri. Aparat birokrasi diharapkan memiliki jiwa pengabdian dan pelayanan kepada masyarakat (Agus Dwiyanto, 2012 :116).

Tingkat responsibilitas dalam pelayanan sangat mempengaruhi penilaian kinerja dari pegawai dan kualitas pelayanan yang dihasilkan. Kinerja yang baik akan menghasilkan pelayanan yang berkualitas sehingga dalam mengukur kinerja maka dinilai dari kepatuhan terhadap peraturan dan prosedur.

\section{Responsibilitas}

Levine dalam Dwiyanto (2008:143) mengemukakan responsibility atau 
responsibilitas atau tanggungjawab adalah suatu ukuran yang menunjukkan seberapa jauh proses pemberian pelayanan publik dilakukan sesuai dengan prinsip-prinsip atau ketentuan-ketentuan administrasi dan organisasi yang benar dan telah ditetapkan. Dalam pemberian pelayanan memiliki berbagai ketentuan-ketentuan administrasi organisasi dan prinsip-prinsip organisasi yang telah ditetapkan untuk menunjang kualitas tanggungjawab pegawai terhadap kinerja dalam pemberian pelayanan. Berikut ini beberapa ketentuan-ketentuan administrasi organisasi dan prinsip-prinsip organisasi.

Dapat dilihat pemenuhan dimensi responsibility atau tanggungjawab dalam pemberian pelayanan publik sudah cukup baik dalam segi pemberian pelayanan yang sudah jelas dan terarah melalui ketentuan dan prinsip. Tetapi masih memiliki sejumlah perbaikan pelayanan dalam dimensi Responsibility atau tanggungjawab seperti masih kurangnya tenaga ASN dan tenaga honorer yang mendominasi pemberian pelayanan. Sehingga ada beberapa pegawai yang memiliki skill dan keterampilan yang masih dibawah standar serta sikap acuh tak acuh yang dimiliki, etika moral yang masih rendah.

\section{Transparansi}

Transparansi adalah keterbukaan atas semua tindakan dan kebijakan yang diambil oleh pemerintah. Prinsip transparansi menciptakan kepercayaan timbal-balik antara pemerintah dan masyarakat melalui penyediaan informasi dan menjamin kemudahan di dalam memperoleh informasi yang akurat dan memadai.

Informasi merupakan suatu kebutuhan penting masyarakat untuk berpartisipasi dalam pengelolaan daerah. Berkaitan dengan hal tersebut pemerintah daerah perlu proaktif dalam memberikan informasi lengkap tentang kebijakan dan layanan yang disediakan kepada masyarakat. Pemerintah daerah perlu mendayagunakan berbagai jalur komunikasi seperti melalui brosur, pengumuman melalui koran, radio, serta televisi, serta kebijakan yang jelas tentang cara mendapatkan informasi. Kebijakan ini akan memperjelas bentuk informasi yang dapat di akses masyarakat ataupun bentuk informasi yang bersifat rahasia, bagaimana cara mendapatkan informasi, lama waktu mendapatkan informasi serta prosedur pengaduan apabila informasi tidak sampai kepada masyarakat.

Transparansi juga harus seimbang dengan kebutuhan akan kerahasiaan lembaga maupun informasi-informasi yang mempengaruhi hak privasi individu. Karena pemerintahan menghasilkan data dalam jumlah besar, maka dibutuhkan petugas informasi professional, bukan untuk membuat dalih atas keputusan pemerintah, tetapi untuk menyebarluaskan keputusan keputusan yang penting kepada masyarakat serta menjelaskan alasan dari setiap kebijakan tersebut.

Peran media juga sangat penting bagi transparansi pemerintah, baik sebagai sebuah kesempatan untuk berkomunikasi pada publik maupun menjelaskan berbagai informasi yang relevan atas berbagai aksi pemerintah dan perilaku menyimpang dari para aparat birokrasi. Jelas, media tidak akan dapat melakukan tugas ini tanpa adanya kebebasan pers, bebas dari intervensi pemerintah maupun pengaruh kepentingan bisnis. Indikator yang digunakan BAPPENAS untuk mengukur transparansi adalah sebagai berikut :

- Tersedianya informasi yang memadai pada setiap proses penyusunan dan implementasi kebijakan publik;

- Adanya akses pada informasi yang siap, mudah dijangkau, bebas diperoleh, dan tepat waktu.

Perangkat Pendukung

1.Peraturan yang menjamin hak untuk mendapatkan informasi;

2. Website (e-government, dsb);

3. Iklan layanan masyarakat;

4. Media cetak dan elektronik;

5. Papan pengumuman;

Transparansi pemerintahan dengan indikator yang disebutkan di atas memungkinkan tumbuhnya peran serta masyarakat. Dengan demikian pemerintahan 
yang transparan perlu dilengkapi dengan tersedianya akses masyarakat dalam berpartisipasi.

\section{METODE PENELITIAN}

Berdasarkan jenis masalah yang diteliti dan tujuannya, penelitian ini adalah penelitian deskriptif kualitatif. Penelitian deskriptif kualitatif adalah prosedur penelitian yang menghasilkan data deskriptif berupa kata-kata tertulis atau lisan dari orang-orang dan perilaku yang diamati (Sugiyono, 2009). Penelitian deskriptif kualitatif selalu berusaha mengungkap suatu masalah, keadaan atau peristiwa sebagaimana adanya. Hasil penelitian diarahkan dan ditekankan pada upaya memberi gambaran subyektif dan sedetail mungkin tentang keadaan yang sebenarnya dari obyek studi dan untuk mendapatkan data yang di butuhkan peneliti melakukan observasi, wawancara, dan dokumentasi.

\section{HASIL PENELITIAN DAN PEMBAHASAN}

\section{Transparansi Badan Pengelolaan Keuangan Daerah Provinsi Bengkulu}

Badan Pengelolaan Keuangan daerah Provinsi Bengkulu melaksanakan proses kegiatan pelayanannya dengan transparan agar dapat membantu proses pelayanan dan kepercayaan dari masyarakat. Bentuk transparansi yang dilakukan oleh Badan Pengelolaan Keuangan Daerah Provinsi Bengkulu dalam pelayanannya kepada masyarakat.

Hasil penelitian ini sejalan dengan hasil penelitian Novatianti dan Nurmalita (2015), Mayasari (2012), Yuliusman (2012), Pramita dan Lilik (2010). Novatianti dan Nurmalita (2015) mengemukakan bahwa Anggota dewan harus dapat mempertanggung jawabkan dalam hal menyajikan, melaporkan, dan mengungkapkan segala aktifitas kegiatan yang dilakukan oleh anggota dewan yaitu salah satunya aktifitas pengawasan keuangan daerah. Dengan ini, dewan dapat memperlihatkan kepada masyarakat bahwa mereka mampu dalam menggunakan anggaran dengan baik karena masyarakat memiliki hak dan kewenangannya atas pertanggungjawaban tersebut. Dengan demikian semakin tinggi responsibilitas maka semakin tinggi pula kualitas layanan yang dihasilkan.

\section{Responsibilitas Badan Pengelolaan Keuangan Daerah Provinsi Bengkulu}

Pada dasarnya konsep responsibilitas berawal dari konsep pertanggungjawaban, konsep pertanggungjawaban sendiri dapat dijelaskan dari adanya wewenang. Wewenang di sini berarti kekuasaan yang sah. Menurut Weber ada tiga macam tipe ideal wewenang, pertama wewenang tradisional kedua wewenang karismatik dan ketiga wewenang legal rational. Yang ketigalah ini yang menjadi basis wewenang pemerintah. Dalam perkembanganya, muncul konsep baru tentang wewenang yang dikembangkan oleh Chester I. Barnard, yang bermuara pada prinsip bahwa penggunaan wewenang harus dapat dipertanggungjawabkan. Darwin sebagaimana dikutip Joko Widodo, membedakan konsep pertanggungjawaban menjadi tiga .

1. Akuntabilitas (accountability),

2. Responsibilitas (responsibility) dan

3. Responsivitas (responsiveness).

Sebelum menjelaskan tentang pertanggungajawaban sebagai responsibilitas (accountability), di sini akan dijelaskan lebih dahulu pertanggungjawaban sebagai responsibilitas (responsibility) dan sebagai responsivitas (responsiveness). Responsibilitas (responsibility) merupakan konsep yang berkenaan dengan standar profesional dan kompetensi teknis yang dimiliki administrator (birokrasi publik) dalam menjalankan tugasnya. Administrasi negara dinilai responsibel apabila pelakunya memiliki standard profesionalisme atau kompetensi teknis yang tinggi. Sedangkan konsep responsivitas (responsiveness) merupakan pertanggungjawaban dari sisi yang menerima pelayanan (masyarakat). 
Seberapa jauh mereka melihat administrasi negara (birokrasi publik) bersikap tanggap (responsive) yang lebih tinggi terhadap apa yang menjadi permasalahan, kebutuhan, keluhan dan aspirasi mereka.

Pertanggungjawaban sebagai responsibilitas (acountability) merupakan suatu istilah yang pada awalnya diterapkan untuk mengukur apakah dana publik telah digunakan secara tepat untuk tujuan di mana dana publik tadi ditetapkan dan tidak digunakan secara ilegal. Dalam perkembanganya responsibilitas digunakan juga bagi pemerintah untuk melihat responsibilitas efisiensi ekonomi program. Usaha-usaha tadi berusaha untuk mencari dan menemukan apakah ada penyimpangan staf atau tidak, tidak efisien apa tidak prosedur yang tidak diperlukan.

Responsibilitas dibedakan dalam beberapa macam atau tipe, Jabra \& Dwidevi sebagaiman dijelaskan oleh Sadu Wasistiono mengemukakan adanya lima perspektif responsibilitas yaitu:

1. Responsibilitas administatif/organisasi adalah pertanggungajwaban antara pejabat yang berwenang dengan unit bawahannya dalam hubungan hierarki yang jelas.

2. Responsibilitas legal, responsibilitas jenis ini merujuk pada domain publik dikaitkan dengan proses legislatif dan yudikatif. Bentuknya dapat berupa peninjauan kembali kebijakan yang telah diambil oleh pejabat publik maupun pembatalan suatu peraturan oleh institusi yudikatif. Ukuran responsibilitas legal adalah peraturan perundang undangan yang berlaku.

3. Responsibilitas politik, dalam tipe ini terkait dengan adanya kewenangan pemegang kekuasaan politik untuk mengatur, menetapkan prioritas dan pendistribusian sumber-sumber dab menjamain adanya kepatuhan melaksanakan tanggungjawab administrasi dan legal. Responsibilitas ini memusatkan pada tekanan demokratik yang dinyatakan oleh administrasi publik.
4. Responsibilitas profesional hal ini berkaitan dengan pelaksnaan kinerja dan tindakan berdasarkan tolak ukur yang ditetapkan oleh orang profesi yang sejenis. Responsibilitas ini lebih menekankan pada aspek kualitas kinerja dan tindakan.

5. Responsibilitas moral. Akuntabilitas ini berkaitan dengan tata nilai yang berlaku di kalagan masyarakat. Hal ini lebih banyak berbicara tentang baik atau buruknya suatu kinerja atau tindakan yang dilakukan oleh seseorang/badan hukum/pimpinan kolektif berdasarkan ukuran tata nilai yang berlaku setempat.

\section{PENUTUP \\ Kesimpulan}

Berdasarkan pembahasan yang telah diuraikan di atas, maka dapat diperoleh kesimpulan sebagai berikut:

1. Transparansi di Badan Pengelolaan Keuangan Daerah Provinsi Bengkulu berdasarkan penelitian yang dilakukan, Badan Pegelolaan Keuangan Daerah Provinsi Bengkulu telah menjalankan prinsip transparansi untuk membantu dalam pemberian pelayanan kepada masyarakat yaitu membantu memudahkan pembayaran. Adapun mekanisme pembayaran yang dilakukan oleh Badan Pegelolaan Keuangan Daerah Provinsi Bengkulu adalah transparan kepada masyarakat dan pelaporannya kepada pemerintah pusat dapat dikatakan baik karena terarah dan langsung dipantau oleh pemerintah pusat.

2. Penerapan prinsip responsibilitas di Badan Pegelolaan Keuangan Daerah Provinsi Bengkulu dapat dilihat dari sejauh mana pelaksanaan kegiatan Badan Pegelolaan Keuangan Daerah Provinsi Bengkulu dalam menjalankan tugas dan tanggungjawabnya kepada masyarakat misalnya dengan adanya kepuasan pelayanan kepada masyarakat, oleh sebab itu kendala yang di dapat dalam responsiblitas ini yaitu pada pelayanan yang diberikan belum memuaskan bagi 
masyarakat karena belum lengkapkan fasilitas kantor Badan Pegelolaan Keuangan Daerah Provinsi Bengkulu yang sesuai dengan prinsip yang berlaku misalnya masih panasnya ruangan tempat pelayanan masyarakat, kurangnya tempat duduk dan lainnya

\section{DAFTAR PUSTAKA}

A.S, Moenir. 2002. Manajemen Pelayanan Umum di Indonesia. Jakarta, Bumi

Anggita. 2015. Pengaruh Responsibilitas dan Sikap Kerja Terhadap Kualitas Pelayanan Di Kelurahan Tengah Kecamatan Cibinong Kabupaten Bogor. Jurnal Penelitian. Volume. VII No. 2 September 2015

Agoes, Sukrisno dan I Cenik Ardana. 2009. Etika Bisnis dan Profesi. Jakarta, Salemba Empat

Aisyah, 2015. Pengaruh Akuntabilitas Dan Transparansi Terhadap Kinerja Pelayanan Publik Di Kantor Samsat Jakarta Barat. Jurnal Universitas Mercubuana Vol 4 No 5

Azheri, Busyra, 2012. Corporate Social Responsibility. Jakarta, Raja Grafindo. Persada

Handoko, T. Hani. 2009. Manajemen. Cetakan Dua Puluh. Yogyakarta, Penerbit. BPEE
Hardiyansyah. 2011. Kualitas Pelayanan Publik Konsep Dimensi, Indikator dan Implementasinya. Yogyakarta, Gavamedia

Kertonegoro. 2002. Manajemen SDM untuk Perusahaan dari Teori ke Praktik. Jakarta, PT Raja Grafindo Persada.

Kurniawan, 2005. Transformasi Pelayanan Publik. Yogyakarta: Pembaharuan

KBBI, Edisi Ketiga, 2003. Oxford English Reference Dictionary

Hessel Nogi S. 2005. Manajemen Publik. Jakarta, Gramedia Widia

Mahsun, Mohama. 2006. Pengukuran Kinerja Sektor Publik. Yogyakarta, Penerbit BPFE

Moleong, Lexy. J. 2004. Metode Penelitian Kualitatif. Bandung, Remaja Rosdakarya.

Rusmiati. Transparansi Pelayanan Pajak Kendaraan Bermotor Di Kabupaten Gowa. Vol. IV No. 2 Oktober 2014

Sembiring, Masana. 2012. Budaya \& Kinerja Organisasi : Perspektif Organisasi Pemerintah. Bandung, Fokus Media.

Sugiyono. 2013. Metode Penelitian Kombinasi (Mixed Methods). Bandung, Alfabeta

Syafrudin, dkk. 2011. Manajemen Mutu Pelayanan. Jakarta, Trans Info Media 
Jurnal Professional FIS UNIVED Vol.7 No.1 Juni 2020 